\title{
The Impact of Organizational Slack on The Performance of Pharmaceutical and Chemical Firms
}

\author{
Heping Zhong
}

School of Economics and Management, Xuchang University, Xuchang, China

\begin{abstract}
The purpose of this paper is to attempt to reconcile previous views of the relationship between organizational slack and performance through examining the impact of organizational slack on the performance of pharmaceutical and chemical firms by using empirical analysis based on the data get from 47 firms in Henan Province. The result shows that the relationship between organizational slack and the performance of pharmaceutical and chemical firms is inverse $\mathrm{N}$-shaped. The results broadly demonstrate that relationships differ based on industry circumstances and organizational slack. Additionally, this study is the first to empirically identify an inverse $\mathrm{N}$-shaped relationship between slack and performance, indicating that, in certain industry circumstances, little and much slack is bad for performance. Overall, results highlight the importance of additional research into intervening factors impacting the slack-performance relationship.
\end{abstract}

Index Terms: Pharmaceutical and chemical firm; organizational slack; performance; pharmaceutical and chemical industry; pharmaceutical and chemical firm management; inverse $\mathrm{N}$-shaped curve; software application; empirical analysis

(C) 2011 Published by MECS Publisher. Selection and/or peer review under responsibility of the Research Association of Modern Education and Computer Science.

\section{Introduction}

Organizations are continually challenged to foster growth and improve performance while enduring strong exogenous pressures and endogenous constraints. Management scholars have offered strategic and behavioral explanations of factors that induce or impel organizations to compete and excel in these evolving competitive landscapes. An emergent dialog within this paradigm is the role of resources and their influence on managers' aspirations. Resources act as inducements to experiment, take risks, and make proactive strategic choices. Resources are also deployed to build capabilities that make firms competitive, maintain coalitions that ensure the convergence of personal and organizational goals, and act as buffers in periods of economic duress[1]. In this regard, numerous studies have proposed that resources enable firms to create static and dynamic synergies by applying resources required for sustainable development[2]. Given this critical role, the presence or absence of excess resources and their impact on performance carries substantive implications for scholarship in

* Corresponding author.

E-mail address: Hepingz2004@163.com 
organizational theory and the practice of management[1]. Consequently, how to optimize firm resource allocation and its impact on performance has substantive theoretical and practical implications[3].

However, despite the importance of firm resource allocation, the existing literature provides no compelling answers regarding whether slack resources facilitates or inhibits performance[3-5]. What is the relationship between organizational slack and performance? Based on prior findings, the slack-performance relationship is generally conceptualized as a positive[6,7], negative[8], an inverted U-shaped relationship[5,9,10], or a Ushaped relationship[3]. The current literature has not reconciled these perspectives, and the issue regarding the influence of slack resources on performance remains an interesting but not fully explored issue[3,5].

Such ambiguity can arise from many sources including random variation due to differing sample sizes across studies (i.e., "sampling error") and inconsistent variable measurement [11]. Examining the slack-performance literature suggests that both these sources may be present. Whereas overall evidence suggests that slack directly affects performance, findings remain too inconclusive to make a definitive statement about the relationship[12].

To provide insight into this relationship, this study employed a empirical analysis based on 47 samples from pharmaceutical and chemical firms in Henan Province to examine extant research results. Specifically, I focus on firms of a industry in China, based on survey data, to investigate whether slack resources contributes toward or inhibits firm performance.

\section{Theoretical Background And Hypothesis}

Organizational slack has been defined in the literature in different ways. For example, Cyert and March defined organizational slack as "the disparity between the resources available to the organization and the payments required to maintain the coalition"[7]. Similarly, Bourgeois (1981) defined organizational slack as resources in excess of what is required for the efficient operation of a firm[9]. Also, Nohria and Gulati defined organizational slack as "the pool of resources in an organization that is in excess of the minimum necessary to produce a given level of organizational output"[13]. For the purposes of this study, organizational slack will be defined as the resources readily available to an organization that are in excess of the minimum necessary to produce a given level of organizational output as well as the resources that are recoverable from being embedded in the firm[14].

In theory, if a firm can identify and obtain resources for firm development from its interior or exterior timely and accurately, and maintain the sum of resources which meets the need of current business exactly, namely, the amount of slack resources is zero, the performance would reach the optimization, but it is impossible in practice. In order to respond to problems such as fluctuations in demand, a firm should have to keep some slack resources, which would lead to increasing cost. In order to fulfill the commitment to the staff, take on some social responsibilities and maintain harmony and stability of the organization, a firm should have to keep certain slack resources, this would also increase cost[15]. In pursuit of new goals and strategies, a firm should have to keep some slack resources[16], this would increase cost because the slack resources could not produce performance before new strategy is put in practice. So the conclusion is made that organizational slack on the low side is negatively related to the performance of pharmaceutical and chemical firms.

When there is moderate organizational slack, a firm has capability to explore and take advantage of opportunity provided by environment. The firms with slack have more strategic choices than those without slack[18,19], thereby they could choose strategic opportunities supported by organizational slack available to enhance performance. Bromiely (1991) argued that slack resources related to competition provide strategic advantage for firms[19], as a result, there is a conclusion that to enhance slack resources related to competition will strengthen the firm's competitive advantage and improve performance. In a word, moderate organizational slack enables managers to pursue new targets and strategies actively, which may leads to improvement of firm performance. From the viewpoint of resource-based theory, the more organizational slack a firm has, the more potential growth and better performance a firm has[16]. Therefore, we could draw a conclusion that moderate organizational slack will be positively related to the performance of pharmaceutical and chemical firms. 
On the other hand, organizational slack is argued to be synonymous with waste, and a sign of managerial selfinterest, incompetence, and sloth. From an agency theory perspective, managers inherently have a set of goals, such as the pursuit of power, prestige, money, and job security, that are not always aligned with those of principals, managers may use organizational slack to engage in excessive diversification, empire-building, and on-the-job shirking[5]. These "slack as inefficiency" perspective posits that slack can encourage satisficing, politics, or self-serving managerial behaviors that hurt performance. At the same time, too much slack resources would encourage a firm to choose some suboptimal projects [13]; and it would reduce firms' performance. So, we can reach a conclusion that organizational slack on the high side will be negatively related to the performance of pharmaceutical and chemical firms. Based on above discussion, we put forward hypothesis as following:

Hypothesis1: Organizational slack on the low side is negatively related to the performance of pharmaceutical and chemical firms.

Hypothesis2: Moderate organizational slack is positively related to the performance of pharmaceutical and chemical firms.

Hypothesis3: Organizational slack on the high side is negatively related to the performance of pharmaceutical and chemical firms.

Hypothesis4: There is a nonlinear inverted $\mathrm{N}$-shaped relationship between organizational slack and the performance of pharmaceutical and chemical firms. That is to say, when organizational slack is on the low side, organizational slack is negatively related to the performance of pharmaceutical and chemical firms; when organizational slack is moderate, organizational slack is positively related to the performance of pharmaceutical and chemical firms; when organizational slack is on the high side, organizational slack is negatively related to the performance of pharmaceutical and chemical firms.

\section{Methodology}

\section{A. Samples}

The sample was drawn from pharmaceutical and chemical firms in Henan province by questionnaire. We randomly selected 47 firms. The questionnaire was accomplished by intermediate and senior managers. The firms' ownership distributing is: state-owned (42.6\%), private-owned (55.3\%), foreign capital-owned $(2.1 \%)$. The scale of enterprise distributing is: big (27.6\%), middle (51.1\%) and small (21.3\%).

\section{B. Variables measure}

Firm performance: There are great numbers of measurements on firm performance in present literatures, such as financial performance, strategy performance and so on. Because the statistical data is distempered or not willing to publish in many firms, it is hard to measure in quantity. But in their practical activities, managers collect and hold some useful information about their opponents in their industry, so they are clear about the comparative level of performance of their firm. Thereby, I use for reference measure item of prior studies[15,19], use the method of perception to measure comparative level of firm performance compared with its main opponents. So this paper chooses four items to measure firm performance: (1) sales growth; (2) assetprofit ratio; (3) increase of market share; and (4) net profit. In the questionnaires the answers were measured on 5-point Likert scale, using the scale from 1, strongly draggle, to 5, strongly keep ahead.

Organizational slack: The measure of organizational slack borrow from the studies of Fang \& Wang (2008)[20,21]. According to their definition and characteristics of the organizational slack, this paper measure organizational slack from the two aspects of the shared level of resources(reflecting the use range of resources as well as the conversion efficiency among differnet uses of the resources) and the multi-purpose in nature(reflecting the use range of resources), mainly choose three items to measure the level of organizational slack: (1) The resource sharing level of various departments within the firm is very high; (2) New uses of existing resources in a firm are often found; (3) Some new resources or new mix of existing resources in a firm 
are often found. In the questionnaires the answers were measured on 5-point Likert scale, using the scale from 1, strongly disagree, to 5 , strongly agree.

Control variable: Like prior studies, this study adopts total capital to measure the size of a firm, and take it as a control variable. The competition pressure that a firm faces is more big, the resources of the firm are more needed more effective exploitation. Since the competition condition among firms in different industry, this study also take the competition condition in a industry as a control variable, which is measured on 5-point Likert scale, using the scale from 1-5, which means respectively few competition, not severe competition, general, severe competition and very severe competition.

\section{Results}

I test my model with the statistical software SPSS 13.0 and use exploratory factor analysis to test every index. In order to test the hypothesis all above, the paper draws on methods from Nohria \& Gulati (1996), Jiang \& Zhao(2004), Zhong et al(2008), uses once, twice, thrice regression equation model including independent variable to process hypothesis testing. The regression equation model is as follow:

$$
\begin{aligned}
& \text { performance }= \\
& \beta_{0}+\beta_{1} \text { size }+\beta_{2} \operatorname{comp}+\beta_{3} \operatorname{var}+\beta_{4} \operatorname{var}^{2}+\beta_{5} \operatorname{var}^{3}+\varepsilon
\end{aligned}
$$

I use the method of stepwise regression, and all variables are standardized before regresion analysis. If thrice regression equation model is better than model including once and twice regression equation, the $\mathrm{N}$-shaped or inverted N-shaped relationship would be existed[1,15,19]. The result of hypothesis testing show as Table 1 to Table 3.

Table 1 Model factor loading of the elements and Cronbach's $\alpha$

\begin{tabular}{|l|c|}
\hline Elements discribing indicators (N=54) & Factor loading \\
\hline \multicolumn{1}{|c|}{ Firm performance (Cronbach's $\alpha=0.927)$} & 0.926 \\
\hline V1 Sales growth Organizational slack (Cronbach's $\alpha=0.840)$ & 0.918 \\
\hline V2 Asset profit ratio & 0.881 \\
\hline V3 Increase of market share & 0.906 \\
\hline V4 Net profit & 0.802 \\
\hline $\begin{array}{l}\text { V5 The resource sharing level of various departments } \\
\text { within the firm is very high }\end{array}$ & 0.917 \\
\hline V6 New uses of existing resources in a firm are often found & 0.889 \\
\hline $\begin{array}{l}\text { V7 Some new resources or new mix of existing resources } \\
\text { in a firm are often found }\end{array}$ & \\
\hline
\end{tabular}

Table 2 Means, standard deviations and correlations

\begin{tabular}{|l|c|c|c|c|c|}
\hline variables & mean & s.d. & 1 & 2 & 3 \\
\hline 1 Firm size & 49138 & 120702 & & & \\
\hline 2 Competition & 4.109 & 0.9939 & 0.094 & & \\
\hline 3 Organizational slack & 3.7408 & 1.16424 & -0.094 & -0.020 & \\
\hline 4 Firm performance & 3.4330 & 0.80726 & $0.257^{+}$ & 0.012 & $0.372 *$ \\
\hline
\end{tabular}

$* * * \mathrm{p}<0.001 * * \mathrm{p}<0.01 * \mathrm{p}<0.05{ }^{+} \mathrm{p}<0.10$ 
Table 3 Regression model of organizational slack and firm performance

\begin{tabular}{|l|l|l|l|l|}
\hline variables & Model 1 & Model 2 & Model 3 & Model 4 \\
\hline Firm size & $0.294^{+}$ & $0.335^{*}$ & $0.288^{*}$ & $0.329^{* *}$ \\
\hline Competition & $-0.318^{*}$ & $-0.348^{* *}$ & $-0.293^{*}$ & $-0.337^{* *}$ \\
\hline Organizational slack & & $0.491^{* * *}$ & $0.429^{* *}$ & $0.935^{* *}$ \\
\hline Organizational slack & & & $-0.243^{+}$ & $-0.321^{*}$ \\
\hline Organizational slack & & & & $-0.589^{*}$ \\
\hline $\mathrm{F}$ & & $8.766^{* * *}$ & $7.883^{* * *}$ & $8.004^{* * *}$ \\
\hline $\mathrm{R}^{2}$ & $3.998^{*}$ & 0.409 & 0.460 & 0.526 \\
\hline Adjusted $\mathrm{R}^{2}$ & 0.170 & 0.362 & 0.402 & 0.461 \\
\hline$* * * \mathrm{p}<0.001 * * \mathrm{p}<0.01 * \mathrm{p}<0.05^{+} \mathrm{p}<0.10$ & 0.128 &
\end{tabular}

Note: Regression coefficients are standardized coefficients

The result of exploratory factor analysis from Table 1 indicate that factor loading and Cronbach's alpha are more than 0.70 , every index is in accordance with requirement of hypothesis testing. Goodness-of-Fit test and significance test from Table 3 indicate that model 4 is better than model 2 and model 3. Model 4 contains every hypothesis, that is negative relationship when there are slack resources on the low side, positive relationship when there are moderate slack resources; negative relationship when there are slack resources on the high side $\left.{ }_{(} \beta_{3}=0.935, \mathrm{p}=0.001 ; \beta_{4}=-0.321, \mathrm{p}=0.017 ; \beta_{5}=-0.589, \mathrm{p}=0.031\right)$. Meanwhile, collinearity and heteroscedasticity test indicate that there is no multicollinearity problems and heteroscedasticity issues (relevant test data are ignored). Therefore, all hypotheses from hypothesis 1 to hypothesis 4 are supported by these testing. Regression curve as Fig. 1 (control variable is ignored).

\section{Firm Performance}

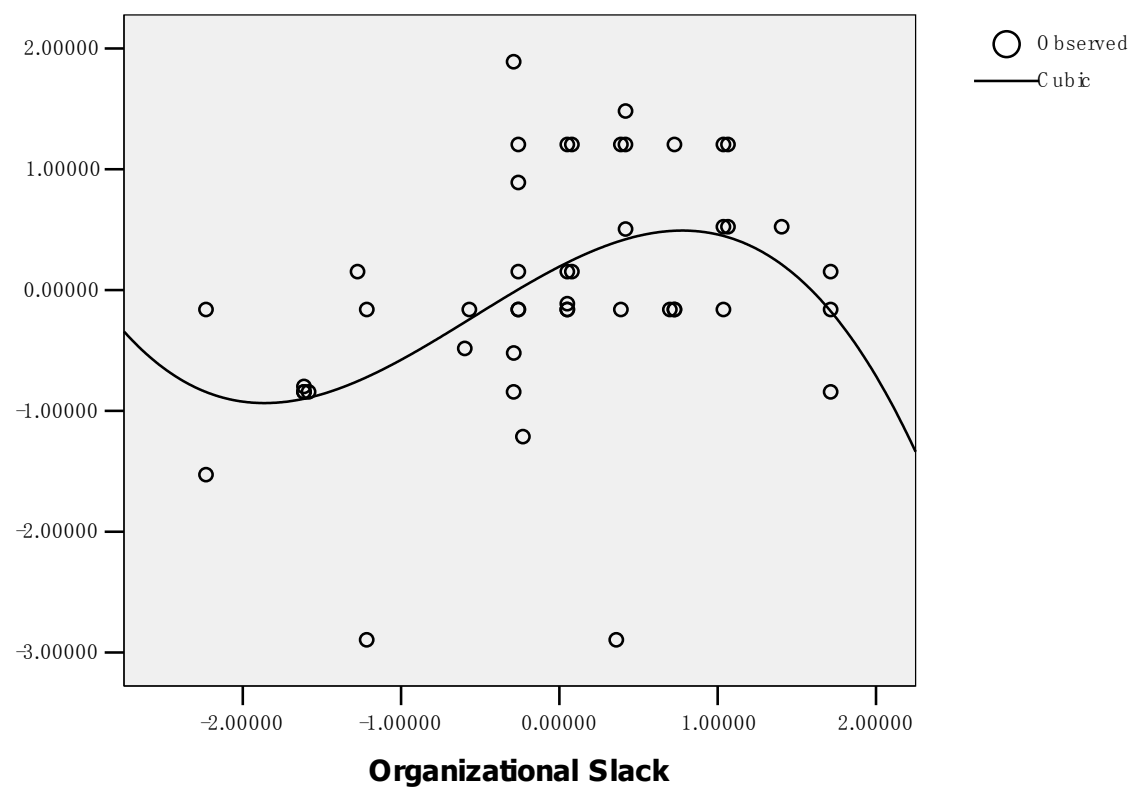

Fig. 1 Regression curve 


\section{Discussion And Conclusion}

In this study, my contributions focus on the building of an inverted N-shaped model that clarify the relationship between organizational slack and the performance of pharmaceutical and chemical firms, and I examine the effects of manufacturing firms' slack resources on firm performance in China. The results indicate that keeping moderate slack resources is propitious to firm development, but little and much slack resources may reduce firm performance. Therefore, it provides a firm a theoretical basis for a firm to cut slack resources.

Although this study's findings provide support for the general proposition that there is a curvilinear relationship between slack resources and performance in at least one industry, my findings differ from former researches because I suggest an inverted N-shaped model between organizational slack and firm performance. As such, it represents another demonstration that the seemingly contradictory attributions made to slack resources can be reconciled when explaining the impact of slack on performance. Furthermore, this study uses different methods to measure slack resources, which is not only measure the slack of the amount of resources but also measure the slack of the value of resources. Therefore, this study's finding is an important extension of the Tan and Peng (2003) findings in that it was based on using financial measures of slack.

Because of data limitations, this paper only studies firms in Henan Province, the universality of its conclusions shall be tested by the firms of other regions in future. Of course, other environment variables, such as industry, location, age of companies, ownership structure and so on, may have an impact on the relationship between slack resources and the performance of information technology firms, which provides opportunity for future research efforts.

\section{Acknowledgment}

This paper is supported by Natural Science Foundation of China (70671111), the Soft Science Research Project of Henan Province (092400440088), the Natural Science Research Program of Henan Education department (2008A630041) and the Major Special Project of Xuchang University (2010ZD007).

\section{References}

[1] George,G. Slack resources and the performance of privately held firms[J]. Academy of Management Journal, 2005,48(4):661-676.

[2] Foss, N.J. and Christensen, J.F. A market-process approach to corporate coherence[J]. Managerial and Decision Economics, 2001, 22(4/5):213-26.

[3] Yi-Chia Chiu, Yi-Ching Liaw. Organizational slack: is more or less better?[J]. Journal of Organizational Change Management, 2009, 22(3):321-342.

[4] Singh J. Performance, slack, and risk taking in organizational decision making[J]. Acad Manage J, 1986, 29:562-85.

[5] Tan, J., Peng, M. W. Organizational Slack and Firm Performance During Economic Transitions: Two Studies from an Emerging Economy[J]. Strategy Management Journal, 2003, 24(13): 1249-1263.

[6] Penrose E. "The theory of the growth of the firm". Oxford: Oxford University Press, 1959.

[7] Cyert,R.M., March,J.G. A behavioral theory of the firm[M]. Prentice-Hall, Englewood Cliffs, NJ. 1963.

[8] Jensen M. Agency costs of free cash flow, corporate finance, and takeovers. Am Econ Rev 1986;76:3239.

[9] Bourgeois L. On the measurement of organizational slack. Acad Manage Rev, 1981, 6:29- 39.

[10] Sharfman, M. P., Wolf, G., Chase, R. B., \& Tansik, D. A. Antecedents of organizational slack[J]. Academy of Management Review, 1988,13(4): 601-614.

[11] Francis Daniel et al. Slack resources and firm performance: a meta-analysis[J]. Journal of Business Research, 2004,57:565-574. 
[12] Greenley G, Okemgil M. A comparison of slack resources in high and low performing British companies. J Manage Stud 1998;35:377-98.

[13] Nohria, N., Gulati, R. Is slack good or bad for innovation? [J]. Academy of Management Journal, 1996, 39 (5): 1245-1264.

[14] Geiger,S.W., Makri,M.. Exploration and exploitation innovation process: The role of organizational slack in R \& D intensive firms[J]. Journal of High Technology Management Research, 2006,17(1): 97-108.

[15] Zhong Heping,Fang Runsheng,Sun Lianjian,Sun Xinqing. Human Resource Slack and Performance: Evidence from Henan Province in China[C]. Proceedings of The Second International Conference on Management Science and Engineering Management. England:World Academic Union,2008:513-519.

[16] Mishina, Y., Pollock, T.G., \& Porac, J.F. "Are more resources always better for growth? Resource stickiness in market and product expansion". Strategic Management Journal, 2004, 25(12): 1179-1197.

[17] Thompson J. Organization in Action. McGraw-Hill: New York. 1967.

[18] Bromiley, P. Testing a causal model of corporate risk taking and performance[J]. Academy of Management Journal, 1991, 34(1):37-59.

[19] Jiang, C.Y\&Zhao, S.M.2004.The relationship between organizational slack and performance: an empirical study. Journal of management world, 5,108-115. (In Chinese).

[20] Fang, R.S\&Wang, C.L. On the Relationship Between Types of Decision-making and Organizational Slac[J]. R\&DMANAGEMEN, 2008, 20(5):47-51. (In Chinese)

[21] Zhong Heping. The Impact of Organizational Slack on Technological Innovation: Evidence from Henan Province in China[C]. The $4^{\text {th }}$ International Conference on Management and Service Science, 2010. 